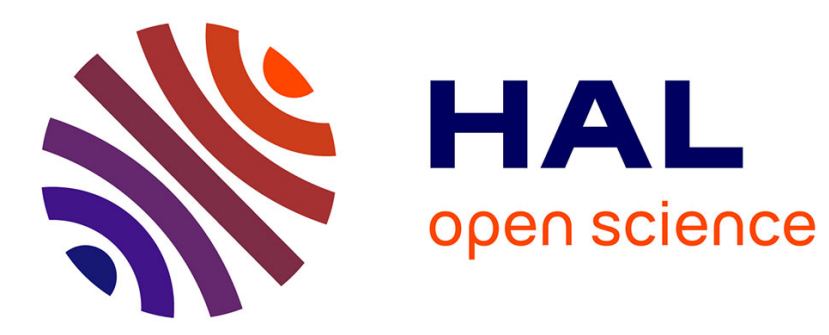

\title{
ScCO2 assisted preparation of supported metal NPs. Application to catalyst design.
}

Oana Pascu, Bastien Cacciuttolo, Samuel Marre, Mathieu Pucheault, Cyril Aymonier

\section{- To cite this version:}

Oana Pascu, Bastien Cacciuttolo, Samuel Marre, Mathieu Pucheault, Cyril Aymonier. ScCO2 assisted preparation of supported metal NPs. Application to catalyst design.. Journal of Supercritical Fluids, 2015, 105, pp.84-91. 10.1016/j.supflu.2014.11.013 . hal-01212321

HAL Id: hal-01212321

https://hal.science/hal-01212321

Submitted on 25 Jun 2021

HAL is a multi-disciplinary open access archive for the deposit and dissemination of scientific research documents, whether they are published or not. The documents may come from teaching and research institutions in France or abroad, or from public or private research centers.
L'archive ouverte pluridisciplinaire HAL, est destinée au dépôt et à la diffusion de documents scientifiques de niveau recherche, publiés ou non, émanant des établissements d'enseignement et de recherche français ou étrangers, des laboratoires publics ou privés. 


\section{$\mathrm{ScCO}_{2}$ assisted preparation of supported metal NPs. Application to catalyst design}

Oana Pascu ${ }^{a}$, Bastien Cacciuttolo ${ }^{b}$, Samuel Marre ${ }^{a}$, Mathieu Pucheault ${ }^{b^{*}}$, Cyril Aymonier $^{\mathrm{a}^{*}}$

${ }^{a}$ CNRS, Univ. Bordeaux, ICMCB, UPR 9048, F-33600 Pessac, France

${ }^{\mathrm{b}}$ CNRS, Univ. Bordeaux, ISM, UMR 5255, F-33405 Talence, France

* Corresponding author at: Mathieu Pucheault, ISM 351 cours de la libération, 33405 Talence Cedex, France. mathieu.pucheault@u-bordeaux.fr

* Corresponding author at: Cyril Aymonier, ICMCB-CNRS, 87, Avenue du Dr. Albert Schweitzer, 33608 Pessac Cedex, France. cyril.aymonier@icmcb.cnrs.fr

\section{Abstract}

Designing and developing materials with specific properties are nowadays important tasks. These could be achieved by choosing the adequate conditions, from a myriad of possibilities, being aware that slight changes in the preparation method could have major impact on the final material. With the work presented here, we are showing that kinetically controlled surface nano-structuring (NPs formation and deposition over solid supports) in $\mathrm{scCO}_{2}$ is a versatile way for preparing active materials. Size, composition, morphology and organization/architecture of supported metal NPs can be controlled by playing with the type of metal, metal precursor, reaction media composition (stronger or weaker reducing media) and different supports employed. Moreover, direct correlation between physical (size, morphology, organization) and chemical properties (composition, surface chemistry) are demonstrated with the systems catalytic behaviour, yield and selectivity, exemplified with $\mathrm{N}$-alkylation reaction of amines with alcohols.

Keywords : scCO2 / Supported metal nanoparticles / Kinetic control / Oxide support / Nanoparticles synthesis.

\section{Introduction}

Formation of nanostructured materials, such as supported metal nanoparticles (NPs) on high specific surface area solids, presenting high interest in catalysis, is an intensively studied field [1-3]. The solid could act as a passive support (e.g. $\left.\mathrm{SiO}_{2}\right)$, but also as an active one (e.g. $\mathrm{CeO}_{2}, \mathrm{TiO}_{2}$, etc.) thus influencing the physicochemical properties of the whole system. The properties of supported metal NPs could arise from the NPs characteristics (size, morphology, composition), their dispersion/organization on the support and the metal-oxide support interaction implicitly affecting the electronic properties of the metal. In addition the metal-support interaction could impact the particle morphology causing metal to grow sometimes in an unusual way [2]. This diversifies the directions for designing and developing materials with specific properties. In terms of applied fabrication technology, the list is large, from physical (e.g. sonication, microwaves, plasma, etc.) to chemical (coprecipitation, impregnation, supercritical fluids/chemical vapour deposition, emulsions, photochemistry, etc.) methods, but all directing to be more sustainable [1]. 
As already reported in some previous reviews [4-7], the design of advanced nanostructured materials with controlled physicochemical properties, e.g. size, morphology, composition and structure, can be achieved via supercritical fluids technology. By using supercritical fluid chemical deposition process, the material surface can be engineered either by the most common thermodynamically controlled metal precursor adsorption/sorption followed by its chemical transformation [5], [6], [8-11], or under kinetic control, playing with nucleation and growth of metal nanoparticles in supercritical fluids [4], [12-15]. In the case of kinetically controlled surface nano-structuring, the metal precursor, usually bearing $\beta$-ketonates counter-anion undergoes a reduction with $\mathrm{H}_{2}$, [13-15] and/or alcohol [16]. The previous studies of our group [13], [14] showed that deposition of Cu NPs onto $\mathrm{SiO}_{2}$ surface at relatively low temperatures $\left(100-150{ }^{\circ} \mathrm{C}\right)$ takes place following a kinetic bimodal process: first a homogeneous nucleation in supercritical media and second - a heterogeneous growth of Cu NPs either by coalescence of nuclei or direct reduction of precursor over the existing nuclei. In the absence of specific interaction between silica and copper, spherical $\mathrm{Cu}$ NPs are formed and their size strongly depends on the reaction temperature. Therefore, understanding process parameters/condition influence on material nano-structuring will help the fabrication of materials with improved properties.

The work presented here aims at bringing a contribution in this direction. Our research is focused on controlling the size, morphology, composition and surface properties of metal nanoparticles (e.g. $\mathrm{Cu}, \mathrm{Sn}, \mathrm{Pt}$ and $\mathrm{Pd}$ ) supported on different oxides under kinetic control. (1) We studied the influence of metal type such as $\mathrm{Cu}, \mathrm{Sn}, \mathrm{Pt}$ and $\mathrm{Pd}$, precursor concentration (metal loading in $\mathrm{wt} \%)$ deposited on the same oxide support $\left(\mathrm{SiO}_{2}\right)$, with direct effect on metal NPs size. (2) By the addition of $\mathrm{H}_{2}$ or different types of surfactants, for example oleic acid, hexadecylamine or sodium dodecyl sulphate to $\mathrm{CO}_{2} / \mathrm{EtOH}$ mixture, the reaction media composition will be changed allowing the NPs morphology, chemical composition and surface chemistry to be controlled. (3) Keeping the same metal (Pd) but changing the oxide type support $\left(\mathrm{SiO}_{2}, \mathrm{CeO}_{2}, \mathrm{TiO}_{2}, \mathrm{Fe}_{2} \mathrm{O}_{3}, \mathrm{ZrO}_{2}\right.$ and $\left.\mathrm{Si}-\mathrm{C}\right)$, different material architectures can be achieved, exhibiting different properties.

For the fabrication of oxide supported metal nanoparticles we have used $\mathrm{scCO}_{2}$ as the main solvent in a batch mode setup, adapting the deposition procedure depending on the targeted material. Additionally, some catalysis results will be shown to illustrate the versatility of this approach for preparing active materials, namely the catalytic activity of Pd NPs, supported on different oxides, in N-alkylation reaction of amines with alcohols [1722] will be exemplified.

\section{Materials and methods}

\subsection{Chemicals}

Different types of precursors were used as metal source, commercially available from Strem Chemicals: anhydrous Copper(II) hexafluoroacetylacetonate $\left(\mathrm{Cu}(\mathrm{hfac})_{2}\right.$, Puratrem, 99.9\%), Bis(2,2,6,6)-tetramethyl-3,5heptadionato copper (II) $\left(\mathrm{Cu}(\mathrm{tmhd})_{2}, 99 \%\right)$, Palladium(II) hexafluoroacetylacetonate $\left(\operatorname{Pd}(\mathrm{hfac})_{2}, 98 \%\right)$, Platinum(II) hexafluoroacetylacetonate $\left(\mathrm{Pt}(\mathrm{hfac})_{2}, 99.9 \%\right)$ and $\mathrm{Tin}(\mathrm{II})$ hexafluoroacetylacetonate $\left(\mathrm{Sn}(\mathrm{hfac})_{2}\right.$, 99.9\%). As surfactants, we used oleic acid (OAc), hexadecylamine (HDA) and sodium dodecyl sulfate (SDS). The support was a Silica Gel-Davisil, grade 710, in the size range of 9.5-11 $\mu \mathrm{m}$ (Sigma-Aldrich). Ceria NPs with mean diameter of $25 \mathrm{~nm}$, titania, zirconia, iron oxide and silicon carbide in the powder form, were purchased from Sigma-Aldrich.

\subsection{Set-up}

In a stainless steel batch reactor of $60 \mathrm{~mL}$ volume (Fig. 1), were mixed in one pot, the support (300 $\mathrm{mg}$ ) with the metal precursor, both in powder form together with $3 \mathrm{~mL}$ of EtOH, used as cosolvent (step I-before reaction). 50 bar of $\mathrm{CO}_{2}$ were first loaded into reactor followed by heating to the desired reaction temperature and further pressurized with $\mathrm{CO}_{2}$. NPs formation and deposition take place during step II-chemical reaction, at the T, P and time considered. At the end of reaction, step III-after reaction, the system was fast depressurised and the reactor cooled with an ice bath. The material was recovered from reactor as dry powder, clean of any undesired organic part, and used for further characterization and catalysis. 


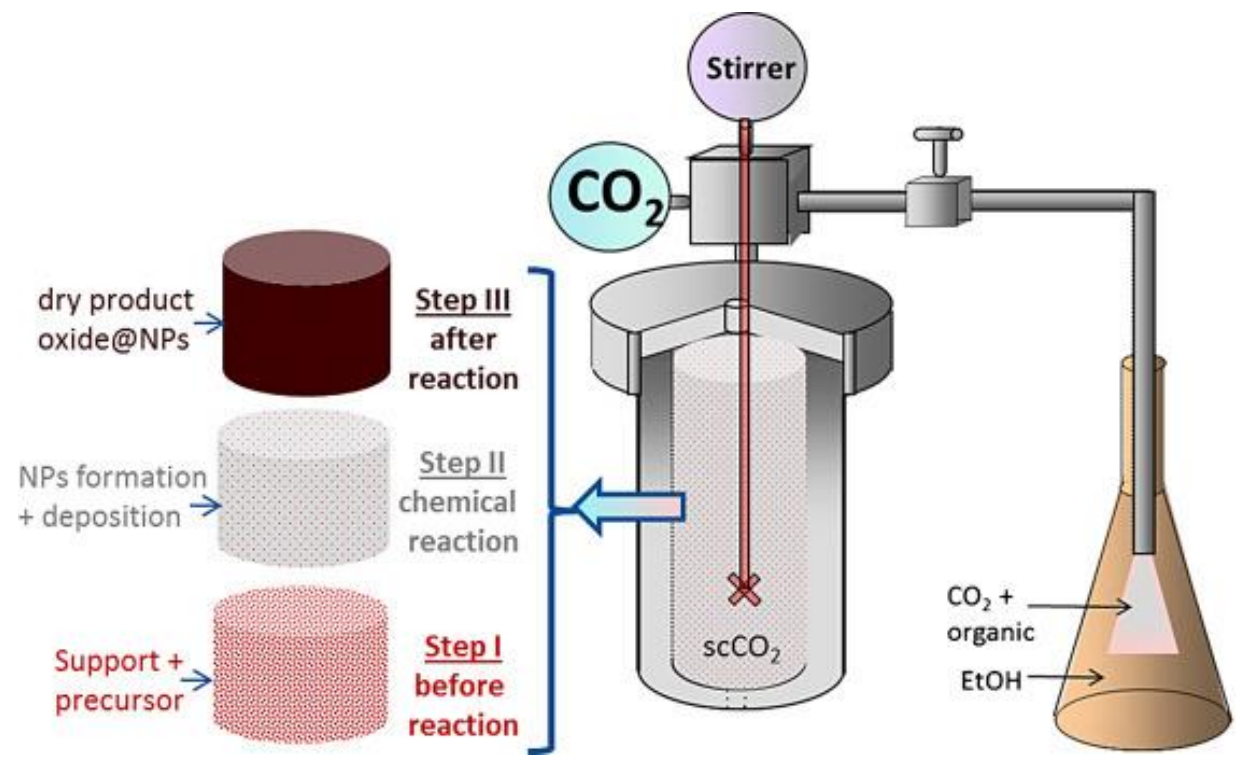

Fig. 1. Sketch of the experimental procedure for the fabrication of supported NPs material.

\subsection{Procedure A: Deposition of metal NPs (Cu, Pt, Sn) on silica support, labelled as: $\mathrm{SiO}_{2} @ \mathrm{Cu}, \mathrm{SiO}_{2} @ P t, \mathrm{SiO}_{2} @ S n$}

$300 \mathrm{mg}$ of silica were mixed with metal hexafluoroacetylacetonate precursor (5 wt $\%$ of metal loading) (Fig. 1 step I). In the absence of $\mathrm{H}_{2}$ as reducing source, we used $\mathrm{EtOH}(3 \mathrm{~mL})$ as cosolvent. In the case of surfactant addition, e.g. OAc, HDA and SDS (the usual surfactant systems for these metals in wet chemistry), a molar ratio to metal of 2 was used. Reaction conditions were set to $200{ }^{\circ} \mathrm{C}, 250$ bar and $30 \mathrm{~min}$ (Fig. 1 - step II), followed at the end of the reaction by fast depressurization and cooling (Fig. 1 - step III). During depressurization, $\mathrm{CO}_{2}$ was purged into $\mathrm{EtOH}$. If some precursor remains unreacted and unbound organic compounds they will be purged together with $\mathrm{CO}_{2}$ in $\mathrm{EtOH}$, colouring the solution in pink or blue-green, depending on the precursor type and metal. By this deposition procedure the interest was: (1) to compare the NPs characteristics (size, morphology and composition) prepared from different metals but using the same precursor ligand and keeping constant the experimental parameters and (2) to study the influence of different surfactants types on the same metal NPs/support. Table 1 presents the description of the used systems.

\subsection{Procedure B: Deposition of Pd NPs on oxides (silica, ceria, titania, iron oxide, zirconia or silicon-carbide) support labelled as $\mathrm{SiO}_{2} @ P d, \mathrm{CeO}_{2} @ P d, \mathrm{TiO}_{2} @ \mathrm{Pd}, \mathrm{ZrO}_{2} @ \mathrm{Pd}, \mathrm{Fe}_{2} \mathrm{O}_{3} @ \mathrm{Pd}$ and SiC@Pd}

A similar procedure was employed, except that also $\mathrm{H}_{2}$ ( 3 bar) was first charged in the reactor before pressuring with $\mathrm{CO}_{2}$. EtOH, with or without HDA surfactant added to the reagents. For $\mathrm{Pd}\left(\left(\mathrm{Pd}(\mathrm{hfac})_{2}\right.\right.$-precursor), the reaction conditions were $100^{\circ} \mathrm{C}, 250 \mathrm{bar}$ and 30 or $60 \mathrm{~min}$ with a metal loading of $15 \mathrm{or} 10 \mathrm{wt} \%$. With procedure $\mathrm{B}$, we have studied the influence of (i) surfactant on the $\mathrm{SiO}_{2} @ \mathrm{Pd}$ NPs morphology and size, (ii) the precursor's concentration (metal loading in wt \%) and also iii) substrate type on Pd NPs characteristics. These systems were tested catalytically in an $\mathrm{N}$-alkylation reaction of amines with alcohols. 
Table 1

Summary of the experimental procedures used for the fabrication of different nanostructured materials.

\begin{tabular}{|c|c|c|c|c|c|c|}
\hline \multirow{2}{*}{$\begin{array}{l}\text { Label } \\
\text { support@M } x \\
M=\text { metal } \\
x=\text { exp no }\end{array}$} & \multicolumn{3}{|l|}{ Reagents } & \multicolumn{3}{|c|}{ Reaction conditions } \\
\hline & Metal loading (wt\%) & Metal precursor & Surfactant & $T\left({ }^{\circ} \mathrm{C}\right)$ & Time (min) & $P($ Bar $)$ \\
\hline \multicolumn{7}{|c|}{ Method A: $\mathrm{scCO}_{2}+$ EtOH, without $\mathrm{H}_{2}$} \\
\hline $\mathrm{SiO}_{2} @ \mathrm{Cu} 1$ & 5 & $\mathrm{Cu}(\mathrm{hfac})_{2}$ & - & 200 & 30 & 250 \\
\hline $\mathrm{SiO}_{2} @ \mathrm{Cu} 2$ & 5 & $\mathrm{Cu}(\mathrm{tmhd})_{2}$ & - & 200 & 30 & 250 \\
\hline $\mathrm{SiO}_{2} @ \mathrm{Cu} 3$ & 5 & $\mathrm{Cu}(\mathrm{hfac})_{2}$ & OAC & 200 & 30 & 250 \\
\hline $\mathrm{SiO}_{2} @ \mathrm{Cu} 4$ & 5 & $\mathrm{Cu}(\mathrm{hfac})_{2}$ & HDA & 200 & 30 & 250 \\
\hline $\mathrm{SiO}_{2} @ \mathrm{Cu} 5$ & 5 & $\mathrm{Cu}(\mathrm{tmhd})_{2}$ & HDA & 200 & 30 & 250 \\
\hline $\mathrm{SiO}_{2} @ \mathrm{CuPt}$ & $\begin{array}{l}2.5 \mathrm{Cu} \\
2.5 \mathrm{Pt}\end{array}$ & $\begin{array}{l}\mathrm{Cu}(\mathrm{hfac})_{2} \\
\mathrm{Pt}(\mathrm{hfac})_{2}\end{array}$ & HDA & 200 & 300 & 250 \\
\hline $\mathrm{SiO}_{2} @ \mathrm{Pt} 1$ & 5 & $\mathrm{Pt}(\mathrm{hfac})_{2}$ & - & 200 & 30 & 250 \\
\hline $\mathrm{SiO}_{2} @ \mathrm{Sn} 1$ & 5 & $\mathrm{Sn}(\mathrm{hfac})_{2}$ & - & 200 & 30 & 250 \\
\hline $\mathrm{SiO}_{2} @ \mathrm{Sn} 2$ & 5 & $\mathrm{Sn}(\mathrm{hfac})_{2}$ & HDA & 200 & 30 & 250 \\
\hline $\mathrm{SiO}_{2} @ \mathrm{Sn} 3$ & 5 & $\mathrm{Sn}(\mathrm{hfac})_{2}$ & SDS & 200 & 30 & 250 \\
\hline \multicolumn{7}{|c|}{ Method B: $\mathrm{scCO}_{2}+$ EtOH, with $\mathrm{H}_{2}$} \\
\hline $\mathrm{SiO}_{2} @ \mathrm{Pd} 1$ & 5 & $\operatorname{Pd}(\text { hfac })_{2}$ & - & 100 & 60 & 250 \\
\hline $\mathrm{SiO}_{2} @ \mathrm{Pd} 2$ & 5 & $\operatorname{Pd}(\text { hfac })_{2}$ & - & 100 & 30 & 250 \\
\hline $\mathrm{SiO}_{2} @ \mathrm{Pd} 4$ & 1 & $\mathrm{Pd}(\mathrm{hfac})_{2}$ & - & 100 & 30 & 250 \\
\hline $\mathrm{SiO}_{2} @ \mathrm{Pd} 3$ & 5 & $\mathrm{Pd}(\mathrm{hfac})_{2}$ & HDA & 100 & 30 & 250 \\
\hline $\mathrm{CeO}_{2} @ \mathrm{Pd} 3$ & 10 & $\mathrm{Pd}(\mathrm{hfac})_{2}$ & - & 100 & 60 & 250 \\
\hline $\mathrm{CeO}_{2} @ P d 1$ & 5 & $\mathrm{Pd}(\mathrm{hfac})_{2}$ & - & 100 & 60 & 250 \\
\hline $\mathrm{CeO}_{2} @ \mathrm{Pd} 2$ & 5 & $\mathrm{Pd}(\mathrm{hfac})_{2}$ & - & 100 & 30 & 250 \\
\hline $\mathrm{CeO}_{2} @ \mathrm{Pd} 4$ & 1 & $\mathrm{Pd}(\mathrm{hfac})_{2}$ & - & 100 & 60 & 250 \\
\hline $\mathrm{CeO}_{2} @ \mathrm{Pd5}$ & 1 & $\mathrm{Pd}(\mathrm{hfac})_{2}$ & HDA & 100 & 60 & 250 \\
\hline $\mathrm{Fe}_{2} \mathrm{O}_{3} @ \mathrm{Pd} 1$ & 1 & $\mathrm{Pd}(\mathrm{hfac})_{2}$ & - & 100 & 60 & 250 \\
\hline $\mathrm{TiO}_{2} @ \mathrm{Pd} 1$ & 1 & $\mathrm{Pd}(\mathrm{hfac})_{2}$ & - & 100 & 60 & 250 \\
\hline $\mathrm{ZrO}_{3} @ \mathrm{Pd} 1$ & 1 & $\mathrm{Pd}(\mathrm{hfac})_{2}$ & - & 100 & 60 & 250 \\
\hline SiC@Pd1 & 1 & $\mathrm{Pd}(\mathrm{hfac})_{2}$ & - & 100 & 60 & 250 \\
\hline
\end{tabular}

\subsection{Characterization}

The size and composition of supported NPs were analyzed by powder XRD diffraction (PANalytical X'Pert Pro with $\mathrm{Cu} \lambda_{\mathrm{K} \alpha}$ radiation) measurements, using Scherrer equation to determine the metal NPs crystallite size. Morphology was studied by scanning or transmission electron microscopy (SEM-JEOL 6700F and TEM-JEOL 2100).

\subsection{Catalysis}

Aniline $(1.0 \mathrm{mmol})$, benzyl alcohol $(2.0 \mathrm{mmol})$, catalyst $(100 \mathrm{mg})$ were added to a $20 \mathrm{~mL}$ pressure tube under argon equipped with a magnetic stirrer. The reaction was heated at $150{ }^{\circ} \mathrm{C}$ for $24 \mathrm{~h}$ then cooled to room temperature and filtered over Celite. The crude reaction mixture was directly analyzed by GC/MS to quantify yields with respect to mesitylene used as an internal standard.

\section{Results and discussion}

With the work presented here, we would like to show how the morphology of nanostructured materials-metal NPs on oxide supports can be tuned just by playing with some experimental parameters.

To deposit the pure metal form on different supports, the most convenient way is the use of $\mathrm{H}_{2}$ as reducing agent, as reported in most published articles. However, the challenge is to find alternative ways, and in the following we are presenting the results obtained when $\mathrm{H}_{2}$ is replaced by other chemical compounds, alcohol as co-solvent or different surfactants. By decomposition onto a silica support of hexafluoroacetylacetonate type metal precursor in a supercritical mixture $\left(200{ }^{\circ} \mathrm{C} / 250\right.$ bar) of $\mathrm{CO}_{2}$ and $\mathrm{EtOH}\left(95: 5\right.$ molar ratio) in the absence of $\mathrm{H}_{2}$, depending on the metal type, pure metal or metal oxide can be obtained. This was observed by powder XRD measurements, presented in Fig. 2a. Being used as a cosolvent, EtOH not only improves the metal precursor dissolution but also serves as reducing agent. If EtOH with a molar fraction of 0.05 in $\mathrm{scCO}_{2}$ is able to reduce completely the $\mathrm{Pt}$, it is 
not strong enough reducer for the $\mathrm{Cu}$ and $\mathrm{Sn}$ since only the metal oxides form being obtained (Fig. 2a). This might happen because $\mathrm{Cu}$ and $\mathrm{Sn}$ are placed much below $\mathrm{Pt}$ in the Ellingham diagram which greatly favour the formation of oxides in a slight reducing atmosphere. Additionally, the presence of $\mathrm{OH}$ groups on the silica support and some $\mathrm{H}_{2} \mathrm{O}$ molecules in EtOH [16] can also act as oxygen source. The Pt and CuO (JCPDS 45-0937) nanocrystalline size determined by XRD Scherrer formula applied on the (1 111 ) peak was $7 \mathrm{~nm}$ and $11 \mathrm{~nm}$, respectively. Unfortunately for $\mathrm{SnO}_{2}$ NPs (JCPDS 41-1445), the diffraction peak was too weak for an accurate size calculation. Changing the $\mathrm{Cu}(\mathrm{hfac})_{2}$ precursor with $\mathrm{Cu}(\mathrm{tmhd})_{2}$ and keeping all the other parameters identical, no diffraction peaks, neither for metal nor metal oxide were observed (Fig. 2b). The different behaviour of two $\mathrm{Cu}$ precursor was somewhat expected since the precursors $\mathrm{Cu}(\mathrm{hfac})_{2}$ and $\mathrm{Cu}(\mathrm{tmhd})_{2}$ has not only a different decomposition temperature of 230 and $260{ }^{\circ} \mathrm{C}$, respectively but also a different thermal decomposition mechanism [23], [24]. This is in agreement with the results obtained by A. Cabanas et al. [25]. They found that $\mathrm{Cu}$, from $\mathrm{Cu}(\mathrm{tmhd})_{2}$ precursor, at $270{ }^{\circ} \mathrm{C}$ and 0.11 molar fraction of $\mathrm{EtOH}$ in $\mathrm{scCO}_{2}$, has not been deposited on $\mathrm{SiO}_{2}$, although the deposition conditions were working for the $\mathrm{Co}$ and $\mathrm{Ni}$ metals. Instead at $300{ }^{\circ} \mathrm{C}, \mathrm{Cu}$ film deposition onto $\mathrm{SiO}_{2}$ support was observed. Surprisingly, in our case by adding HDA surfactant to $\mathrm{CO}_{2}+\mathrm{EtOH}+\mathrm{Cu}(\text { tmhd) })_{2}$ mixture (system labelled $\mathrm{SiO}_{2} @ \mathrm{Cu} 5-$ Table 1) at a reaction temperature of $200{ }^{\circ} \mathrm{C}$, clear XRD diffraction peaks corresponding to $\mathrm{Cu}^{(0)}$ NPs (JCPDS 04-0836) of $25 \mathrm{~nm}$ crystallite size appears (Fig. $2 b)$, the amine type surfactant favouring so the metal formation.
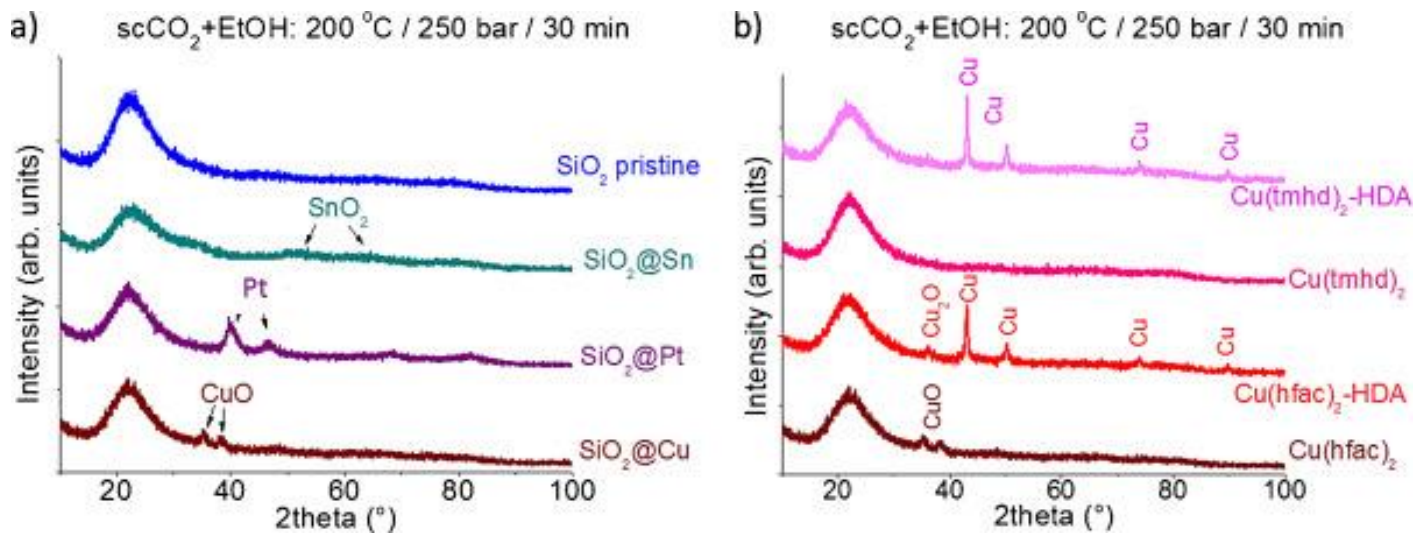

Fig. 2. XRD spectra of different metals NPs decorating the $\mathrm{SiO}_{2}$ support: Pt, Cu and $\mathrm{Sn}$ deposited from hexafluoroacetylacetonate (hfac) type precursor (a); Cu deposited from different precursors without/with HDA surfactant (b).

The same trend is observed with the decomposition of $\mathrm{Cu}(\mathrm{hfac})_{2}$, in $\mathrm{CO}_{2} / \mathrm{EtOH}$ mixture in presence of HDA, $\mathrm{Cu}^{(0)}$ and $\mathrm{Cu}_{2} \mathrm{O}$ (cuprite) NPs being formed, with the predominant $\mathrm{Cu}^{(0)}$ NPs of $\sim 21 \mathrm{~nm}$ size (Fig. 2b). These results clearly show that HDA, initially added as surfactant, is also assisting the reduction of both studied precursors in supercritical $\mathrm{CO}_{2} / \mathrm{EtOH}$ mixture. Changing the amine surfactant with an acid one-oleic acid (more oxidative media), only $\mathrm{Cu}_{2} \mathrm{O}$ (JCPDS 05-0667) NPs with nanocrystalline domains of around $27 \mathrm{~nm}$ were deposited onto silica support (Fig. 3a). $\mathrm{Cu}^{(0)} \mathrm{NPs}$ larger than $20 \mathrm{~nm}$ can be deposited if along EtOH, HDA surfactant is employed. The intention was to deposit smaller $\mathrm{Cu}$ NPs. Experimentally we found that in the same experimental condition, Pt NPs of around $7 \mathrm{~nm}$ can be formed. Hence our question was, what would happen by mixing the two metal precursors, $\mathrm{Cu}(\mathrm{hfac})_{2}$ and $\mathrm{Pt}(\mathrm{hfac})_{2}$ in one to one weight ratio. The result is presented in Fig. 3a. According to XRD diffraction pattern of the system labelled $\mathrm{SiO}_{2} @ \mathrm{CuPt}$, $\mathrm{Cu}_{3} \mathrm{Pt}$ NPs (JCPDS 35-1358) in agreement with others [26], with nanocrystalline domains of $7 \mathrm{~nm}$ were successfully deposited. In the case of a burst nucleation, very small NPs can be obtained as experimentally found for $\mathrm{Cu}-\mathrm{Pt}$ system. Because the decomposition and reducing temperature of $\mathrm{Pt}$ precursor is lower than the one of $\mathrm{Cu}$ precursor, the former could act as catalyst to fasten $\mathrm{Cu}$ precursor decomposition, thus reaching monomer supersaturation very rapidly and implicitly a burst nucleation which will lead to small NPs formation. 
a) $\quad \mathrm{scCO}_{2}+\mathrm{EtOH}: 200^{\circ} \mathrm{C} / 250 \mathrm{bar} / 30 \mathrm{~min}$

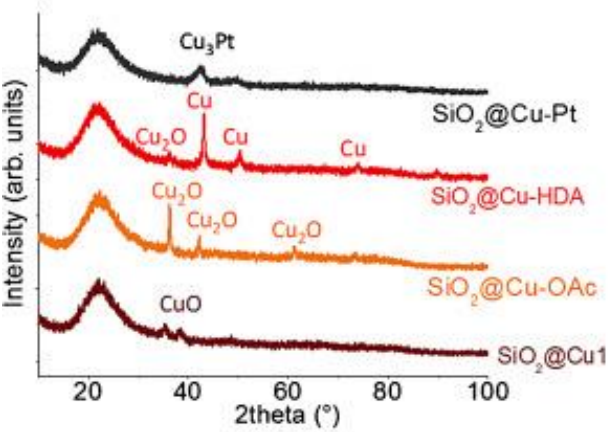

c) $\mathrm{scCO}_{2}+\mathrm{H}_{2}+\mathrm{EtOH}: 100^{\circ} \mathrm{C} / 250 \mathrm{bar} / 20 \mathrm{~min}$

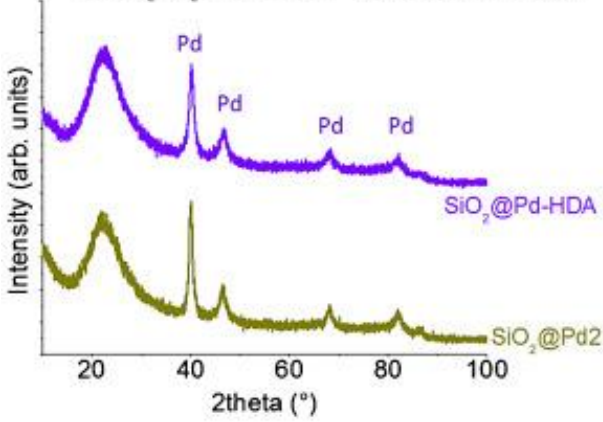

b) $\mathrm{scCO}_{2}+\mathrm{EtOH}: 200^{\circ} \mathrm{C} / 250 \mathrm{bar} / 30 \mathrm{~min}$

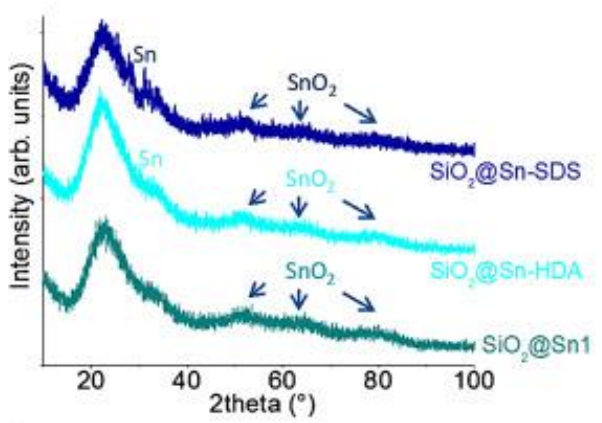

d)

\begin{tabular}{lllc}
\hline label & surfactant & $\begin{array}{c}\text { NPs } \\
\text { composition }\end{array}$ & $\begin{array}{c}\langle\mathbf{( \Phi )} \\
(\mathbf{n m})\end{array}$ \\
\hline $\mathrm{SiO}_{2} @ \mathrm{CU} 1$ & - & $\mathrm{CuO}$ & 11 \\
\hline $\mathrm{SiO}_{2} @ \mathrm{Cu} 3$ & $\mathrm{OAC}$ & $\mathrm{Cu}_{2} \mathrm{O}$ & 27 \\
\hline $\mathrm{SiO}_{2} @ \mathrm{Cu} 4$ & $\mathrm{HDA}$ & $\mathrm{Cu} / \mathrm{Cu}_{2} \mathrm{O}$ & 21 \\
\hline $\mathrm{SiO}_{2} @ \mathrm{CuPt}$ & $\mathrm{HDA}$ & $\mathrm{Cu}_{3} \mathrm{Pt}$ & 7 \\
\hline $\mathrm{SiO}_{2} @ \mathrm{Sn} 1$ & - & $\mathrm{SnO}_{2}$ & - \\
\hline $\mathrm{SiO}_{2} @ \mathrm{Sn} 2$ & $\mathrm{HDA}$ & $\mathrm{SnO}_{2} / \mathrm{Sn}$ & - \\
\hline $\mathrm{SiO}_{2} @ \mathrm{Sn} 3$ & $\mathrm{SDS}$ & $\mathrm{Sn} / \mathrm{SnO}_{2}$ & - \\
\hline $\mathrm{SiO}_{2} @ \mathrm{Pd} 2$ & - & $\mathrm{Pd}$ & 9 \\
\hline $\mathrm{SiO}_{2} @ \mathrm{Pd} 3$ & $\mathrm{HDA}$ & $\mathrm{Pd}$ & 8 \\
\hline
\end{tabular}

Fig. 3. Study of different surfactants influence on three metal type NPs, supported on the same silica support.

If HDA is able to assist $\mathrm{Cu}$ precursor reduction, this is not the case for $\mathrm{Sn}(\mathrm{hfac})_{2}$, in the presence or in the absence of amine surfactant, $\mathrm{SnO}_{2}$ (cassiterite) being deposited. Changing the amine with sodium dodecyl sulphate (SDS) surfactant, the behaviour of the reaction media is modified, leading to a better reduction of the precursor to its metal form (Fig. 3b).

Further we tested the effect of HDA surfactant on the formation of $\mathrm{SiO}_{2} @ \mathrm{Pd} \mathrm{NPs}$, but in the presence of $\mathrm{H}_{2}$. As it is a stronger reducing agent, the amine effect on the Pd NPs size is minor, sizes of 8 (with HDA) and $8.7 \mathrm{~nm}$ (without HDA), respectively (Fig. 3c). On the contrary, a stronger influence of amine surfactant on Pd NPs morphology and oxide supported NPs architecture was observed (discussed later) showing that, in this case, HDA is playing the role of surface modification agent. Analysing the TEM images of the $\mathrm{SiO}_{2} @ \mathrm{Cu} 5, \mathrm{SiO}_{2} @ \mathrm{Pt1}$ and $\mathrm{SiO}_{2} @ \mathrm{CuPt} N \mathrm{NS}$ (Fig. 4), the micrographs reveal a complete coverage of silica support with NPs, forming almost a multi-layered film. This is in agreement with the bimodal mechanism found previously by our group [13], [14]: first - a homogeneous nucleation in supercritical media and second - a heterogeneous growth of NPs by direct reduction of the left precursor over the existing nuclei.
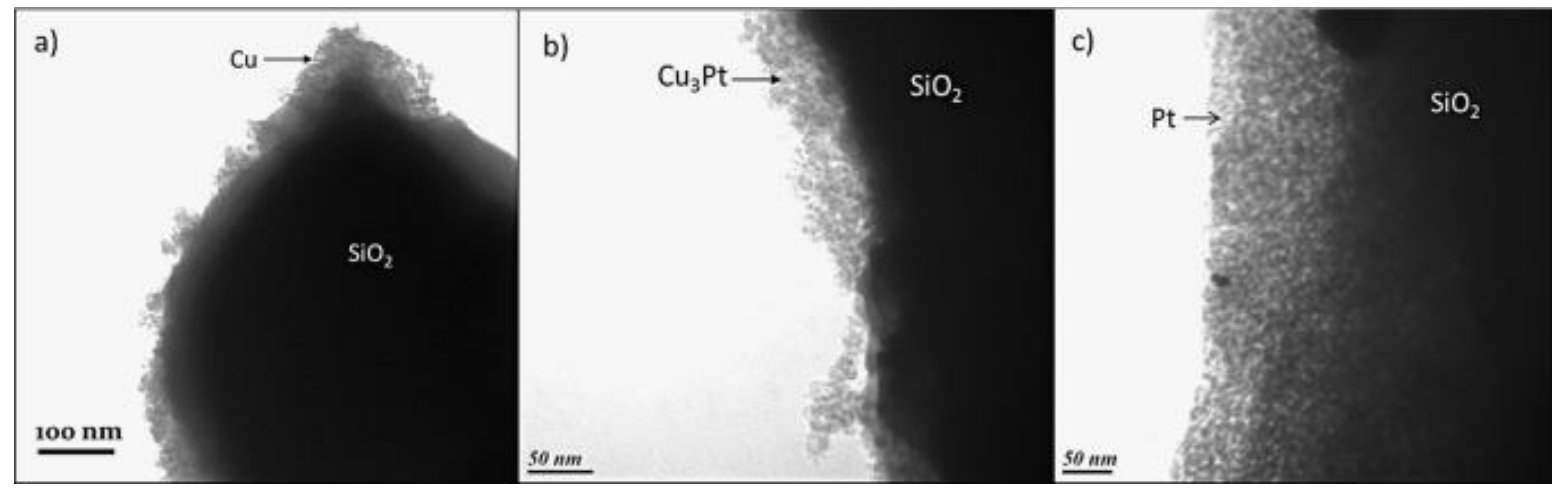

Fig.4.TEM images of silica supported metal NPs: SiO $O_{2} @ C u 5 N P s(a), \mathrm{SiO}_{2} @ C u P t N P s(b)$ and $\mathrm{SiO}_{2} @ P t 1$ NPs $(c)$.

If $\mathrm{Cu}$ and Pt NPs from $h f a c$ type precursor are deposited on silica support as a film made by monodispersed NPs, using the same precursor type and similar conditions the Pd deposition was found to be completely different. 
SEM images of $\mathrm{SiO}_{2} @ P d$ NPs are presented in Fig. 5. Back-scattering images reveal the deposition of Pd NPs in the form of hollow spherical aggregates made by small Pd NPs (Fig. 5c). These aggregates with a mean size of $185 \mathrm{~nm}$ and $35 \%$ polydispersity (Fig. 5a) are quite well dispersed on the silica surface. The architecture conjures up the same bimodal mechanism [13], [14] for NPs formation, but as second step, fast heterogeneous growth of Pd NPs by coalescence of Pd nuclei on the silica surface could be imagined. A tendency of agglomeration of small Pd NPs on another type of support, using the same $\mathrm{Pd}(\mathrm{hfac})_{2}$ precursor in the presence of $\mathrm{H}_{2}$ and $\mathrm{CO}_{2}+\mathrm{EtOH}$ mixture was also reported [27-29].
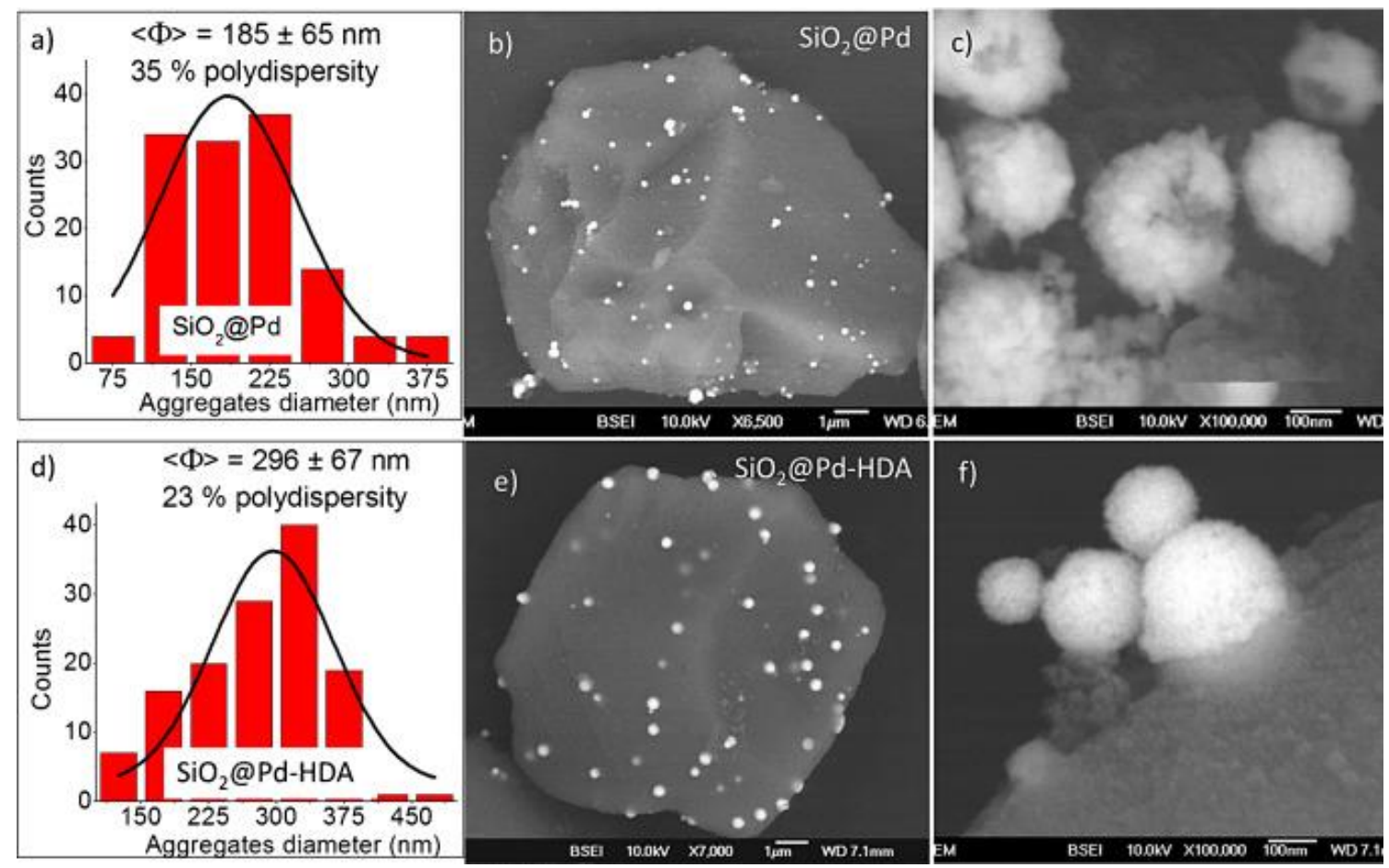

Fig. 5. SEM-back scattering images of $\mathrm{SiO}_{2} @ P d$ without $(a-c)$ or with surfactant $(d-f)$. The small Pd NPs of around $8 \mathrm{~nm}$ are forming spherical aggregates of few hundreds of nm in size organization affected by the presence of surfactant.

However, adding HDA surfactant, homogeneity in NPs size and aggregates deposition occurs. These spheres made by small NPs are larger (Fig. 5d-f), more rounded and compacted. The presence of HDA surfactant seems to decrease the surface energy of Pd NPs being in agreement with their spherical and more compact organization and also might inhibit some of Pd active sites, clearly seen in a different catalytic activity, discussed later in the text. Using a different support such as $\mathrm{CeO}_{2}$, but the same Pd NPs we also studied the influence of HDA on material properties, systems labelled $\mathrm{CeO}_{2} @ \mathrm{Pd} 4$ (without HDA) and $\mathrm{CeO}_{2} @ P d 5$ (with HDA) (Table 1). Unfortunately, due to low metal loading (1 wt\%), it was not possible to detect Pd by XRD measurement (Fig. $6 b)$, but the Pd presence was confirmed by the observed catalytic activity. 

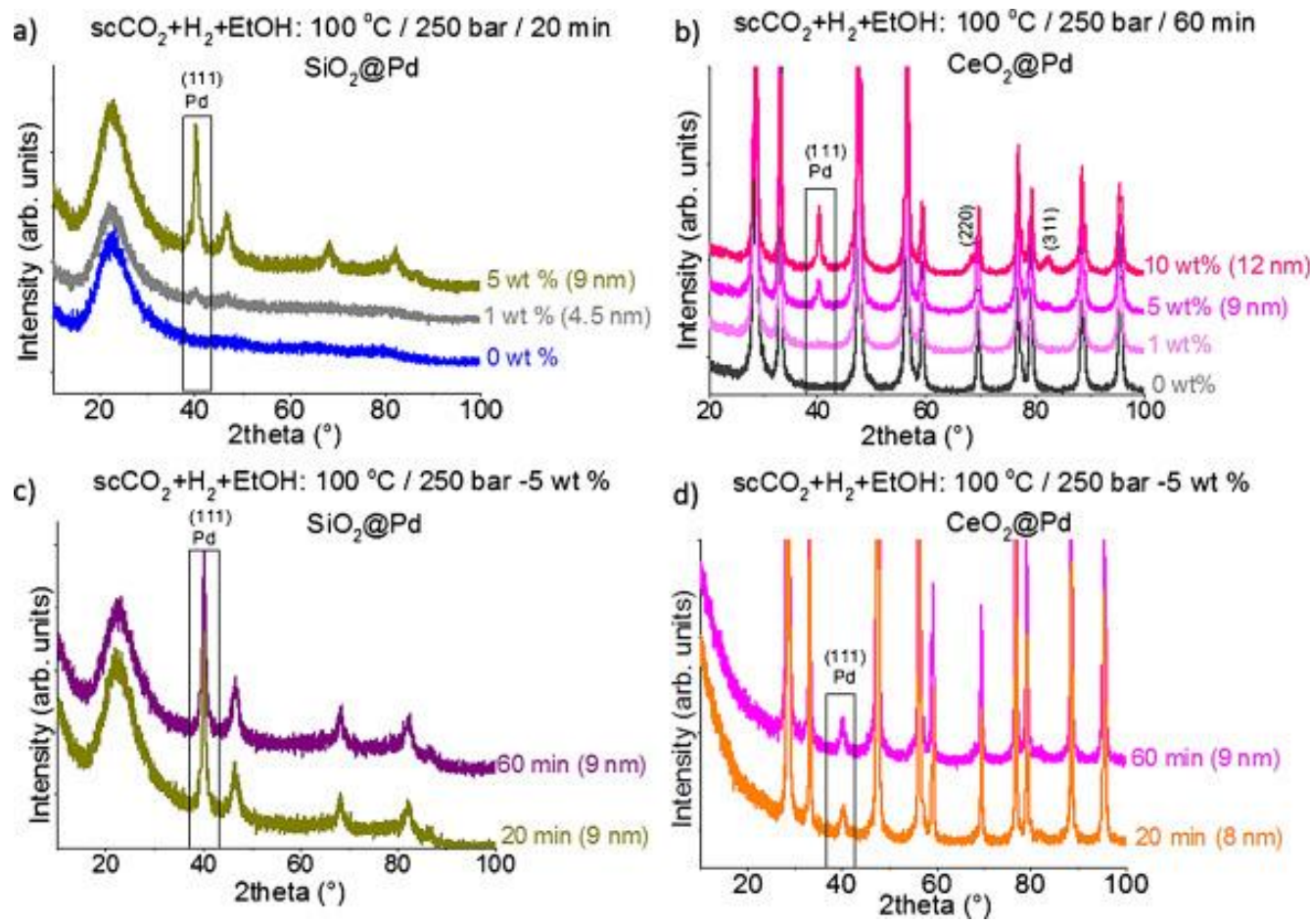

Fig. 6. Comparison between the summative influence of the support type, silica ( $a$ and $c$ ) and ceria ( $b$ and $d)$ on Pd NPs together with either metal loading ( $a$ and $b$ ) or reaction time ( $c$ and $d)$. The crystallite size was calculated for $\left(\begin{array}{lll}1 & 1 & 1\end{array}\right)$ peak, highlighted with a rectangle.

In the following, the research work is devoted to study the influence of metal loading, reaction time together with the support type on Pd NPs size. Fig. 6 is representative for this. As already known, for both thermodynamic and kinetic control of NPs formation, the NPs size could be increased by raising the concentration of metal precursor. We exemplify this control for two systems, namely $\mathrm{SiO}_{2} @ P d$ and $\mathrm{CeO}_{2} @ P d$ NPs, respectively (Fig. 6a and b). For 1 and $5 \mathrm{wt} \%$ metal loading, the size of Pd NPs deposited on $\mathrm{SiO}_{2}$ support was around 4.5 and $9 \mathrm{~nm}$, respectively (Table 1 - labels $\mathrm{SiO}_{2} @ P d 4$ and $\mathrm{SiO}_{2} @ \mathrm{Pd} 2$ ). Keeping the same conditions, but changing only the support, comparable Pd NPs sizes were deposited on $\mathrm{CeO}_{2}$ support (Table 1 - labels $\mathrm{CeO} @ \mathrm{Pd} 5$ for $1 \mathrm{wt} \%$, $\mathrm{CeO}_{2} @ \mathrm{Pdl}$ for $5 \mathrm{wt} \%$, and $\mathrm{CeO}_{2} @ P d 3$ for $10 \mathrm{wt} \%$ ) keeping the same trend: increasing the NPs size with the metal loading (Fig. 6a and b). As expected, changing the size and maybe the surface chemistry, the chemical properties of Pd NPs are changing, affecting directly the obtained catalytic yield. It is important to underline that the support (silica or ceria) has a negligible influence on the Pd NPs size. For 5 wt\% metal loading, Pd NPs have for both supports $\left(\mathrm{SiO}_{2}\right.$ and $\left.\mathrm{CeO}_{2}\right)$ the same size, around $9 \mathrm{~nm}$. The reason could be because NPs formation and deposition is governed by a kinetic control-homogeneous nucleation in the supercritical media followed by heterogeneous growth rather independent of support type. This is also confirmed by the similar sizes, $9 \mathrm{~nm}$ for $\mathrm{Pd}$ deposited on $\mathrm{SiO}_{2}$ or $\mathrm{CeO}_{2}$, when the reaction time was varied, 30 or $60 \mathrm{~min}$ (Fig. 6c and d). The almost constant size for Pd after 30 or $60 \mathrm{~min}$ can be interpreted as fast precursor consumption due to high reactivity of $\mathrm{Pd}$ nuclei and autocatalytic behaviour of $\mathrm{Pd}$. This behaviour is not general for every metal, for example the size of copper NPs can be tuned with the reaction time in low temperature supercritical media, as previously observed by our group [14].

As we have seen so far, size, morphology, composition and organization of the deposited metal NPs can be controlled with type of metal, type of precursor used and reaction media composition (stronger or weaker reducing media). A similar effect can be also achieved by changing the support type. But as it is known, changing the NPs physical properties, undoubtedly NPs chemical properties are changing, exemplified in this work with catalysis data.

\subsection{Catalysis}

For the purpose of using supported Pd NPs as catalyst, materials with $1 \mathrm{wt} \%$ metal loading on different oxides support were prepared, as $\mathrm{SiO}_{2} @ \mathrm{Pd} 4, \mathrm{CeO}_{2} @ P d 4, \mathrm{TiO}_{2} @ P d 1, \mathrm{ZrO}_{2} @ P d 1, \mathrm{Fe}_{2} \mathrm{O}_{3} @ \mathrm{Pd} 1$ and $\mathrm{SiC} @ P d 1$. Without 
any additive or solvent, the previously prepared catalysts were tested in $\mathrm{N}$-alkylation reaction between benzyl alcohol 1 and aniline 2 (Scheme 1) using a borrowing-hydrogen methodology. The catalytic system, by hydrogen transfer, can both oxidize the alcohol 1 and reduce imine intermediate 3 into 4 .

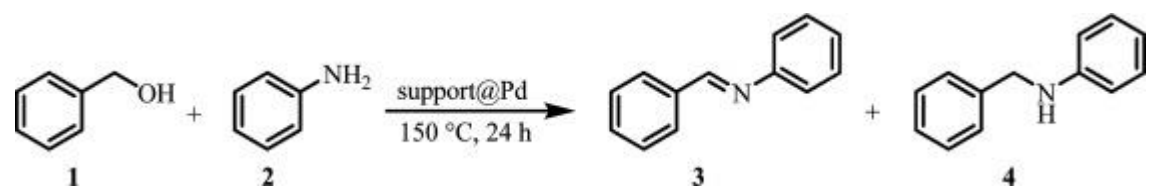

Scheme 1. N-alkylation reaction using as catalysts, oxide supported Pd NPs.

The comparison of catalytic activity of support@Pd led to large differences in reactivity depending on catalyst synthetic protocol (Table 2).

\begin{tabular}{|c|c|c|c|c|}
\hline \multirow[t]{2}{*}{ Entry } & \multirow[t]{2}{*}{ Catalyst (1 mol\%) } & \multirow[t]{2}{*}{ Yield (\%) $4+3$} & \multicolumn{2}{|c|}{ Selectivity (\%) } \\
\hline & & & 3 & 4 \\
\hline 1 & $\mathrm{SiO}_{2} @ \mathrm{Pd} 1$ & 96 & 42 & 58 \\
\hline 2 & $\mathrm{SiO}_{2} @ \mathrm{Pd} 2$ & 95 & 40 & 60 \\
\hline 3 & $\mathrm{SiO}_{2} @ \mathrm{Pd} 3$ & 88 & 82 & 18 \\
\hline 4 & $\mathrm{CeO}_{2} @ \mathrm{Pd} 1$ & 96 & 99 & 1 \\
\hline 5 & $\mathrm{CeO}_{2} @ \mathrm{Pd} 2$ & 95 & 99 & 1 \\
\hline 6 & $\mathrm{CeO}_{2} @ \mathrm{Pd} 3$ & 90 & 99 & 1 \\
\hline 7 & $\mathrm{CeO}_{2} @ \mathrm{Pd} 4$ & 99 & 82 & 18 \\
\hline 8 & $\mathrm{CeO}_{2} @ \mathrm{Pd} 5$ & 99 & 32 & 68 \\
\hline 9 & $\mathrm{Fe}_{2} \mathrm{O}_{3} @ \mathrm{Pd} 1$ & 97 & 87 & 13 \\
\hline 10 & $\mathrm{TiO}_{2} @ \mathrm{Pd} 1$ & 83 & 43 & 57 \\
\hline 11 & $\mathrm{ZrO}_{2} @ \mathrm{Pd} 1$ & 80 & 95 & 5 \\
\hline 12 & Si-C@Pd1 & 50 & 49 & 51 \\
\hline
\end{tabular}

In the case of silica-support, there is a high conversion and with $96 \%$ yield of $\mathbf{3}+\mathbf{4}$ and a majority of amine $\mathbf{4}$ (Table 2, Entry 1). The decrease in catalyst preparation time (60-30 min) has no influence on the yield and selectivity (Table 2, Entry 2), because Pd NPs size is the same. These results demonstrate that even the individual Pd NPs are organized in larger hollow spherical assembly (Fig. 5b) the NPs are still keeping their catalytic activity. Instead, the introduction of the surfactant (HDA) has a negative effect giving a lower yield of $88 \%$ but also a large non reduced imine 3 compared to most desired amine 4 (Table 2, Entry 3). As previously mentioned, adding the HDA, some active site must be blocked and moreover the hollow spheres organization is changed with compact and larger spheres, decreasing the Pd NPs available for the contact with the reagents, lowering such the catalytic activity.

Cerium oxide as a support also allows obtaining a good yield of $96 \%$, but only the imine is formed (Table 2, Entry 4). No effect of catalyst time synthesis was again observed, because the NPs size is maintaining the same (Table 2, Entry 5). The size has a direct influence on catalytic activity, the reaction yield decreased with increasing the metal loading correlated with NPs size as following, 99\% yield for $1 \mathrm{wt} \% \mathrm{Pd}$ loading (Table 2, Entry 7), with an early onset of amine 4 observed, 96\% yield for $5 \mathrm{wt} \%$ Pd loading (Table 2, Entry 6) and 90\% yield for $10 \mathrm{wt} \%$ Pd loading (Table 2, Entry 4), but keeping the same selectivity. The addition of a surfactant on the smaller NPs, contrary to $\mathrm{SiO}_{2}$ support, has a very beneficial effect with $68 \%$ of amine (Table 2, Entry 8). Several other supports were tested without surfactant. Iron oxide provides a good yield of $97 \%$ but a low selectivity for the amine (Table 2, Entry 9). Titanium and zirconium oxide are less effective with lower yields, but with a better selectivity for $\mathrm{TiO}_{2}(57 \%)$ than $\mathrm{ZrO}_{2}(5 \%)$ (Table 2, Entries 10 and 11). Silicon carbide gives less good yield despite a selectivity of $51 \%$ for the amine 4 (Table 2, Entry 12). These different catalytic behaviours arise from Pd NPs different orgnization/architecture with respect to different supports [2], clearly seen in SEM micrographs presented in Fig. 7. In the case of $\mathrm{Pd}$ deposited on $\mathrm{CeO}_{2}$ (Fig. 7a), although a distinction between two materials is difficult to be done, the small Pd aggregates observed being highlighted by white circles, NPs presence is certified by the high reaction yield. On SiC support, Pd NPs organize themselves in aggregates with unusual geometries (Fig. 7c) but 
surprisingly with better selectivity despite the lower yield (Table 2, Entry 12), while on $\mathrm{Fe}_{2} \mathrm{O}_{3}$ support, Pd NPs seem to be smaller and more homogeneous monodispersed (Fig. 7b).

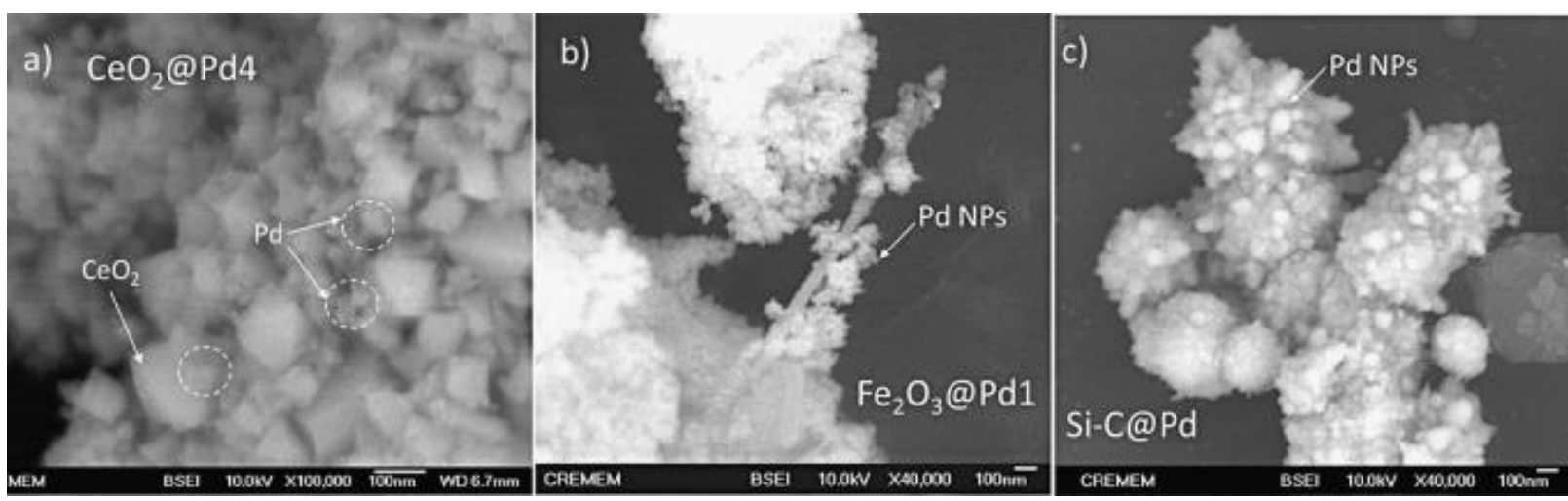

Fig. 7. SEM-back scattering images of Pd NPs on different supports type: silicon carbide (a), iron oxide (b) and ceria (c).

\section{Conclusions}

We have demonstrated that kinetically controlled surface nano-structuring namely supported metal NPs on oxides is a versatile way for preparing active materials. Size, composition and morphology of deposited NPs can be controlled by varying the metal type $(\mathrm{Cu}, \mathrm{Pt}, \mathrm{Sn}$ or $\mathrm{Pd})$, metal precursor type (hfac or tmhd type ligand) and concentration, reaction media composition (presence of EtOH as cosolvent with/without surfactant) as a stronger or weaker reducing media. It was found that organization/architecture of supported NPs depends on the type of metal and support employed; $\mathrm{Cu}$ and $\mathrm{Pt}$ are deposited onto $\mathrm{SiO}_{2}$ as a film made by small monodispersed NPs, while Pd on the same support is forming large spherical aggregates made by small monodispersed NPs. With the addition of a surfactant, especially HDA, in the absence of $\mathrm{H}_{2}$, NPs size and composition can be tuned. On the contrary, when $\mathrm{H}_{2}$ is also present along the surfactant, the NPs size is less affected by the presence of surfactant, but the latter affects instead the NPs organization. Direct correlation between NPs characteristics (size, composition, morphology and organization) and chemical properties were highlighted with systems catalytic behaviour: it was found that catalytic activity, the reaction yield is directly correlated with the NPs size, but the reaction selectivity is influenced more by the presence of amine surfactant and type of solid support used. These certify once again the importance of synthetic method elected which will have a direct influence on the physicochemical properties of the final materials.

Acknowledgments : The authors want to acknowledge the financial support to the Aquitaine region and the ANR-12-CDII-010-NANOCAUSYS.

\section{References}

1. J.M. Campelo, D. Luna, R. Luque, J.M. Marinas, A.A. Romero. Sustainable preparation of supported metal nanoparticles and their applications in catalysis. ChemSusChem, 2 (2009), pp. 18-45.

2. S. Schauermann, N. Nilius, S. Shaikhutdinov, H.-J. Freund. Nanoparticles for heterogeneous catalysis: new mechanistic insight. Accounts of Chemical Research, 46 (2013), pp. 1673-1681.

3. Q. Fu, F. Yang, X. Bao. Interface-confined oxide nanostructures for catalytic oxidation reactions. Accounts of Chemical Research, 46 (2013), pp. 1692-1701.

4. F. Cansell, C. Aymonier. Design of functional nanostructured materials using supercritical fluids. J. Supercritical Fluids, 47 (2009), pp. 508-516.

5. C. Erkey. Preparation of metallic supported nanoparticles and films using supercritical fluid deposition. J. Supercritical Fluids, 47 (2009), pp. 517-522. 
6. S.E. Bozbag, D. Sanli, C. Erkey. Synthesis of nanostructured materials using supercritical $\mathrm{CO}_{2}:$ Part II. Chemical transformations. J. Materials Science, 47 (2012), pp. 3469-3492.

7. C. Aymonier, A. Loppinet-Serani, H. Reveron, Y. Garrabos, F. Cansell. Review of supercritical fluids in inorganic materials science. J. Supercritical Fluids, 38 (2006), pp. 242-251.

8. S.E. Bozbag, U. Unal, M.A. Kurykin, C.J. Ayala, M. Aindow, C. Erkey. Thermodynamic control of metal loading and composition of carbon aerogel supported $\mathrm{Pt}-\mathrm{Cu}$ alloy nanoparticles by supercritical deposition. J. Physical Chemistry C, 117 (2013), pp. 6777-6787.

9. M.J. Tenorio, C. Pando, J.A.R. Renuncio, J.G. Stevens, R.A. Bourne, M. Poliakoff, A. Cabanas. Adsorption of $\mathrm{Pd}(\mathrm{hfac})_{2}$ on mesoporous silica SBA-15 using supercritical $\mathrm{CO}_{2}$ and its role in the performance of $\mathrm{Pd}-\mathrm{SiO}_{2}$ catalyst. J. Supercritical Fluids, 69 (2012), pp. 21-28.

10. T. Hasell, C.D. Wood, R. Clowes, J.T.A. Jones, Y.Z. Khimyak, D.J. Adams, A.I. Cooper. Palladium nanoparticles incorporation in conjugated microporous polymer by supercritical fluid processing. Chemistry of Materials, 22 (2010), pp. 557-564.

11. C.H. Yen, K. Shimizu, Y.-Y. Lin, F. Bailey, I.F. Cheng, C.M. Wai. Chemical fluid deposition of Pt-based bimettalic nanoparticles on multiwalled carbon nanotubes for direct methanol fuel cell applications. Energy \& Fuel, 21 (2007), pp. 2268-2271.

12. M. Majimel, S. Marre, A. Garrido, C. Aymonier. Supercritical fluid chemical deposition as an alternative process to CVD for the surface modification of materials. Chemical Vapor Deposition, 17 (2011), pp. 342-352.

13. S. Marre, F. Cansell, C. Aymonier. Design at the nanometre sale of multifunctional materials using supercritical fluid chemical deposition. Nanotechnology, 17 (2006), pp. 4594-4599.

14. S. Marre, A. Erriguible, A. Perdomo, F. Cansell, F. Marias, C. Aymonier. Kinetically controlled formation of supported nanoparticles in low temperature supercritical media for the development of advanced nanostructured materials. J. Physical Chemistry C, 113 (2009), pp. 5096-5104.

15. J. Zhao, L. Zhang, T. Chen, H. Yu, L. Zhang, H. Xue, H. Hu. Supercritical carbon-dioxide-assisted deposition of Pt nanoparticles on grapheme sheets and their application as an electrocatalyst for direct methanol fuel cells. J. Physical Chemistry C, 116 (2012), pp. 21374-21381.

16. R. Garriga, V. Pessey, F. Weill, B. Chevalier, J. Etourneau, F. Cansell. Kinetic study of chemical transformation in supercritical media of bis(hexafluoroacetylacetonate)copper (II) hydrate. J. Supercritical Fluids, 20 (2001), pp. 55-63.

17. F. Shi, M.K. Tse, S.L. Zhou, M.M. Pohl, J. Radnik, S. Hubner, K. Jahnisch, A. Bruckner, M. Beller. Green and efficient synthesis of sulfonamides catalyzed by nano- $\mathrm{Ru} / \mathrm{Fe}_{3} \mathrm{O}_{4}$. J. American Chemical Society, 131 (2011), pp. $1775-1779$

18. W. He, L.D. Wang, C.L. Sun, K.K. Wu, S.B. He, J.P. Chen, P. Wu, Z.K. Yu. Pt-Sn/ $/-\mathrm{Al}_{2} \mathrm{O}_{3}$-catalyzed highly efficient direct synthesis of secondary and tertiary amines and imines. Chemistry - A European J., 17 (2011), pp. 1330813317.

19. N. Zotova, F.J. Roberts, G.H. Kelsall, A.S. Jessiman, K. Hellgardt, K.K. Hii. Catalysis in flow: Au-catalyzed alkylation of amines by alcohols. Green Chemistry, 14 (2012), pp. 226-232.

20. Y.Q. Zhang, X.W. Wei, R. Yu. $\mathrm{Fe}_{3} \mathrm{O}_{4}$ nanoparticles-supported palladium-bipyridine complex: effective catalyst for Suzuki coupling reaction. Catalysis Letters, 135 (2010), pp. 256-262.

21. L. De Luca, A. Porchedu. Microwave-assisted synthesis of polysubstituted benzimidazoles by heterogeneous Pd-catalyzed oxidative C-H activation of tertiary amines. European J. Organic Chemistry (2011), pp. 5791-5795.

22. Y. Zhang, X.J. Qi, X.J. Cui, F. Shi, Y.Q. Deng. Palladium catalyzed N-alkylation of amines with alcohols. Tetrahedron Letters, 52 (2011), pp. 1334-1338.

23. J.J. Senkevich. ALD seed layers for plating and electroless plating. Y. Shachan-Diamand, T. Osaka, M. Datta, T. Ohba (Eds.), Advanced Nanoscale ULSI Interconnects. Fundamental and Applications, cap 12, Springer Science and Business Media, LLC, New York (2009), pp. 169-183.

24. G.I. Spijksma, H.J.M. Bouwmeester, D.H.A. Blank. Chemistry of 2,2,6,6-tetramethyl-3,5-heptadione (Hthd) modification of zirconium and hafnium propoxide precursors. Inorganic Chemistry, 45 (2006), pp. 4938-4950.

25. A. Cabanas, X. Shan, J.J. Watkins. Alcohol-assisted deposition of copper films from supercritical carbon dioxide. Chemistry of Materials, 15 (2003), pp. 2910-2916.

26. S. Chen, S. Jenkins, J. Tao, Y. Zhu, J. Chen. Anisotropic seeded growth of Cu-M ( $\mathbf{M}=\mathbf{A u}, \mathbf{P t}$ or Pd) bimetallic nanorods with tunable optical and catalytic properties. J. Physical Chemistry C, 117 (2013), pp. 8924-8932. 
27. S. Couillaud, M. Kirikova, W. Zaidi, J.-P. Bonnet, S. Marre, C. Aymonier, J. Zhang, F. Cuevas, M. Latroche, L. Aymard, J.-L. Bonet. Supercritical fluid deposition of Pd nanoparticles on magnesium-scandium alloy for hydrogen storage. J. Alloys and Compounds, 574 (2013), pp. 6-12.

28. A. Denis, E. Sellier, C. Aymonier, J.L. Bobet. Hydrogen sorption properties of magnesium particles decorated with metallic nanoparticles. J. Alloys and Compounds, 476 (2009), pp. 151-159.

29. C. Aymonier, A. Denis, Y. Roig, M. Iturbe, E. Sellier, S. Marre, F. Cansell, J.L. Bobet. Supported metal NPs on magnesium using SCFs for hydrogen storage: interface and interphase characterization. J. Supercritical Fluids, 53 (2010), pp. 102-107. 